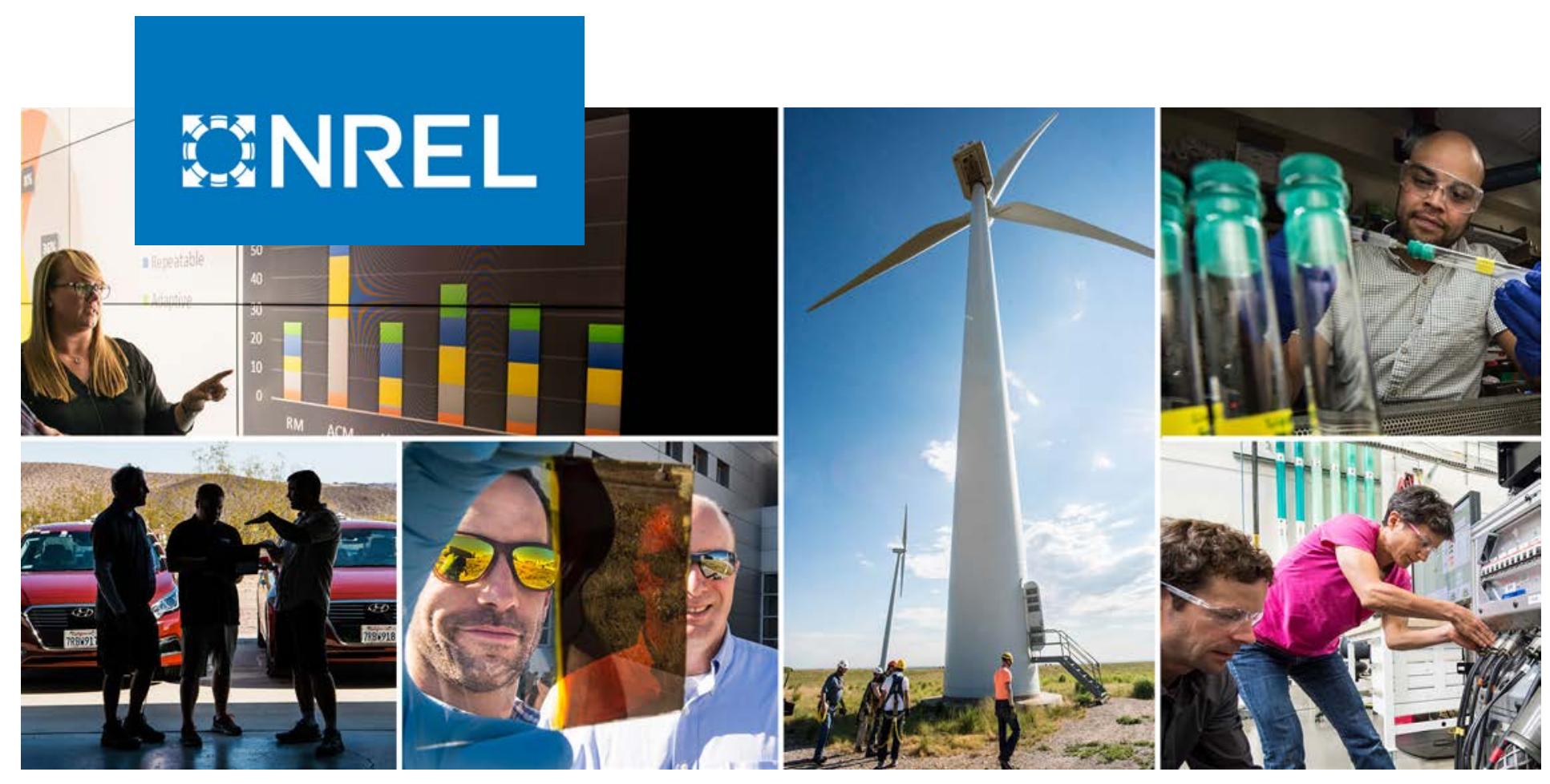

Solar Economies of Scope through the Intersection of Four Industries: PV Installation, Electrical, Construction, and Roofing

Eric O'Shaughnessy and Robert Margolis

National Renewable Energy Laboratory

NREL is a national laboratory of the U.S. Department of Energy

Office of Energy Efficiency \& Renewable Energy

Operated by the Alliance for Sustainable Energy, LLC

This report is available at no cost from the National Renewable Energy Laboratory (NREL) at www.nrel.gov/publications.
Technical Report

NREL/TP-6A20-72171

November 2018 


\title{
WNREL
}

\section{Solar Economies of Scope through the Intersection of Four Industries: PV Installation, Electrical, Construction, and Roofing}

\author{
Eric O'Shaughnessy and Robert Margolis
}

National Renewable Energy Laboratory

\section{Suggested Citation}

O'Shaughnessy, Eric and Robert Margolis. 2018. Solar Economies of Scope through the Intersection of Four Industries: PV Installation, Electrical, Construction, and Roofing.

Golden, CO: National Renewable Energy Laboratory. NREL/TP-6A20-72171.

https://www.nrel.gov/docs/fy19osti/72171.pdf.

NREL is a national laboratory of the U.S. Department of Energy Office of Energy Efficiency \& Renewable Energy Operated by the Alliance for Sustainable Energy, LLC

This report is available at no cost from the National Renewable Energy Laboratory (NREL) at www.nrel.gov/publications.

Contract No. DE-AC36-08GO28308
Technical Report NREL/TP-6A20-72171 November 2018

National Renewable Energy Laboratory 15013 Denver West Parkway Golden, CO 80401

303-275-3000 • www.nrel.gov 


\section{NOTICE}

This work was authored by the National Renewable Energy Laboratory, operated by Alliance for Sustainable Energy, LLC, for the U.S. Department of Energy (DOE) under Contract No. DE-AC36-08G028308. Funding provided by the U.S. Department of Energy Office of Energy Efficiency and Renewable Energy Solar Energy Technologies Office. The views expressed herein do not necessarily represent the views of the DOE or the U.S. Government.

This report is available at no cost from the National Renewable Energy Laboratory (NREL) at www.nrel.gov/publications.

U.S. Department of Energy (DOE) reports produced after 1991 and a growing number of pre-1991 documents are available free via www.OSTI.gov.

Cover Photos by Dennis Schroeder: (clockwise, left to right) NREL 51934, NREL 45897, NREL 42160, NREL 45891, NREL 48097, NREL 46526.

NREL prints on paper that contains recycled content. 


\section{Acknowledgements}

This work was supported by the Solar Energy Technologies Office at the U.S. Department of Energy. The authors would like to thank Anna Ebers (DOE), Andrew Truitt (Distributed Resource Ventures), and Sarah Truitt (NREL) for their thoughtful review of this work, as well as Carolyn Pino (SunStreet) for guidance on installer licensing. The authors would like to also thank Jarett Zuboy (consultant) for editorial support. 


\section{Executive Summary}

Over the past two decades, the U.S. solar photovoltaic (PV) installation industry grew from dozens to hundreds and then thousands of installation companies. The PV installation industry did not emerge from a void. Rather, the industry largely grew from pre-existing industries that provide related services such as electrical contracting, construction, and roofing. In this report, we use a new data set based on data from the California Contractors State License Board (CSLB) to explore the ties between PV installation and these related-service industries.

In California, PV installers are required to obtain at least one of four licenses: electrical, general construction, general building, or a designated solar contractor license. Based on a study period of 2010 to 2016 , the CSLB data show that about $70 \%$ of PV installers hold a single one of those licenses, primarily electrical and general building, and about $25 \%$ of PV installers hold multiple PV-enabling licenses, mostly a combination of electrical and general building licenses (Figure ES-1). Only about $9 \%$ of PV installers hold only the solar contractor license. The fact that most PV installers hold electrician and construction licenses illustrates the important ties between PV installation and these industries. Interestingly, about 5\% of PV installers do not hold any of the PV-enabling licenses, though they hold additional licenses such as roofing. These installers must have collaborated with another licensed installer or subcontractor to secure the permits needed to install the PV system.

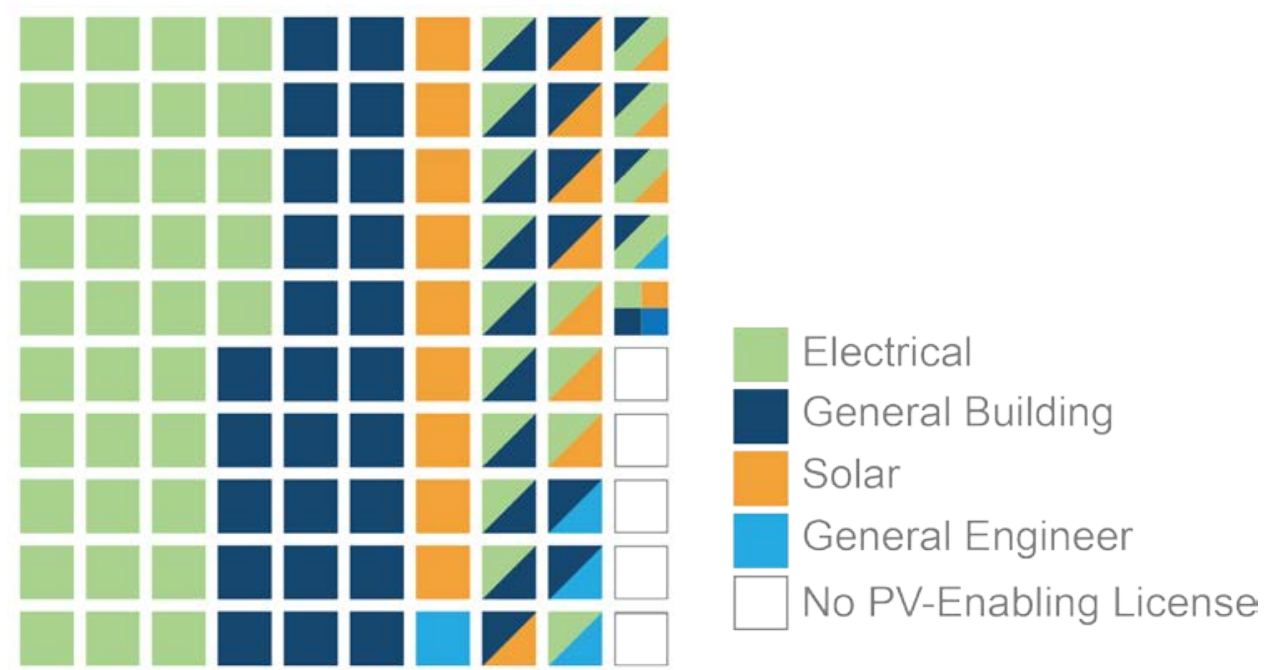

Figure ES-1. Distribution of combinations of licenses held by PV installers in California, 20102016

The CSLB data show that installers of different scales tend to hold different licenses. Small-scale installers are less likely to hold the designated solar contractor license, providing evidence that small-scale installers are primarily related-service contractors that dabble in PV installation. Large-scale installers are more likely to hold general building and roofing licenses. Furthermore, large-scale installers are more likely to install PV systems during new construction. Together, these data suggest that large-scale installers are incorporating multiple services into their business models. 
One key implication of the ties between PV installation and other industries is the potential for economies of scope: the ability to offer two products together at a lower cost than when the products are offered separately. It is possible that installers with multiple skill sets could achieve economies of scope, reduce costs, and offer lower prices than installers dedicated exclusively to PV installation. For instance, an installer with roofing skills may be able to perform jobs on complex roof structures at lower cost than installers without such skills.

Economies of scope may also exist when PV is installed during roof replacement or new construction. Construction and roofing contractors may be able to install roofs and PV systems simultaneously at a lower cost than if the roof and PV system were installed by separate crews. To explore potential economies of scope, we matched the CSLB data with PV price data from the Lawrence Berkeley National Laboratory's Tracking the Sun data set. Our analysis shows that customer-owned residential PV systems installed during new construction are indeed lowerpriced than PV systems installed on existing homes, also known as "retrofits." The lowest-priced systems in the data are new-construction systems installed by licensed roofers (Figure ES-2). These results are consistent with economies of scope: installers with a technical background in roofing appear to achieve lower costs on new construction PV system installation.

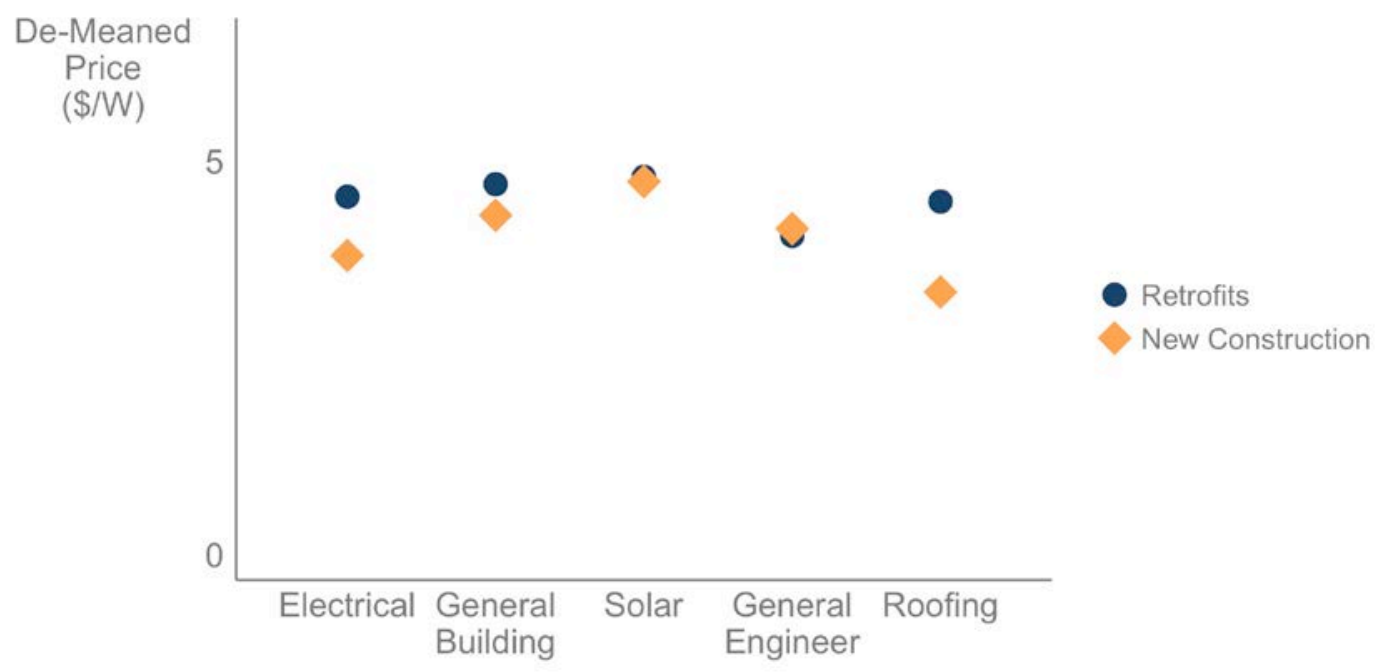

Figure ES-2. Average de-meaned ${ }^{\mathrm{a}}$ prices for retrofits and new-construction systems for installers with different licenses

${ }^{a}$ A de-meaned price factors out price variation resulting from changes in prices over time. See Section 4.

Potential economies of scope in PV installation are particularly relevant in light of recent policy changes in California. In 2018, the California Energy Commission approved building code reforms requiring that all new homes be equipped with PV beginning in 2020. The CSLB data suggest that the existing PV installation, electrical, construction, and roofing industries have enough capacity to meet a large increase in demand for new-construction PV. We estimate that, of the roughly 230,000 contractors from these industries that could have installed a PV system from 2010 to 2016 in California, only about 2\% actually installed PV. The results of this study suggest that the intersection of these four industries could yield lower PV prices in newconstruction PV under the new California building code. 


\section{Table of Contents}

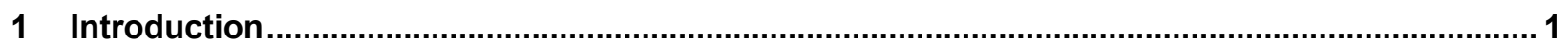

2 Contractor License Data ...................................................................................................... 2

3 License, Scale, and Business-Model Characteristics of PV Installers ........................................ 4

4 Effects of License Portfolios on Customer-Owned Residential PV Prices .................................. 9

4.1 Descriptive Price Statistics ............................................................................ 9

4.2 Econometric Model ............................................................................................. 12

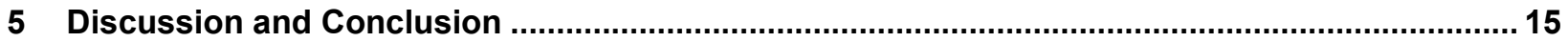

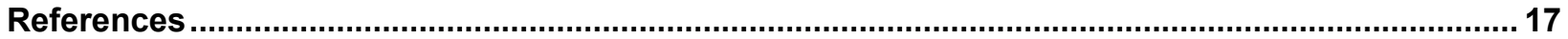

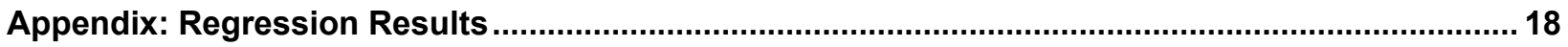




\section{List of Figures}

Figure 1. Distribution of the number of different licenses held by contractors ........................................ 3

Figure 2. Percentage of installers in the study data set that hold different PV-enabling licenses................ 4

Figure 3. Combinations of PV-enabling licenses held by installers ...................................................... 5

Figure 4. Most common non-PV-enabling licenses held by PV installers................................................ 5

Figure 5. Percentage of PV systems installed and percentage of installers by license type ....................... 6

Figure 6. Percentage of PV installers by installer scale and license type ............................................... 6

Figure 7.Combinations of PV-enabling licenses held by established installers and dabblers ................... 7

Figure 8. Correlation between percentage of PV systems installed on new construction and percentage of installers with general building or roofing licenses, by installer scale .............................. 8

Figure 9. Annual mean installed PV prices by license held, 2010-2016 ........................................... 9

Figure 10. De-meaned installed PV price distributions by license held, 2010-2016 ............................. 10

Figure 11. De-meaned average installed PV prices by installer scale for installers with and without a solar contractor license

Figure 12. De-meaned average installed PV prices for retrofit and new-construction systems by license held

Figure 13. Effects of holding different licenses on installed PV prices for retrofit and new construction-

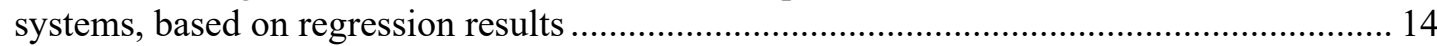

Figure 14. Percentage of licensed contractors that installed PV or not in California, 2010-2016 ............ 15

\section{List of Tables}

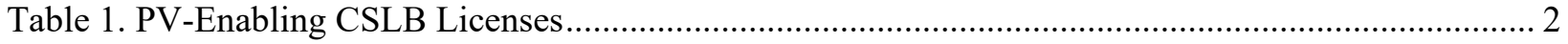

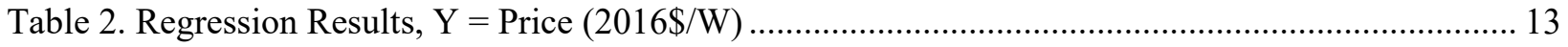

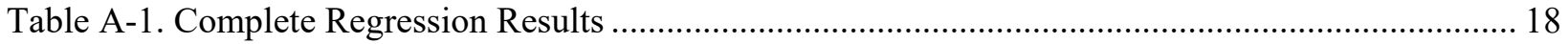




\section{Introduction}

More than 8,700 companies have installed solar photovoltaic (PV) systems in the United States. Some of these companies have grown to install hundreds or thousands of systems per year, but the vast majority have installed only a few systems, with more than 2,000 companies installing a single system (O'Shaughnessy 2018). The relatively small installation scales of most PV installers may reflect ties between PV installation and related industries such as electrical contracting, construction, and roofing. In California - the largest PV market in the United States-licensed electricians, general engineers, and building contractors are permitted to install PV systems. Some licensed contractors may install a single PV system as a trial run, others may dabble in PV installation by installing a few systems per year as a side business, while others may commit resources to PV installation and become specialized PV installers.

The relationships between PV installation and these related industries might produce cost synergies or economies of scope that could be tapped to reduce PV costs and prices and increase PV deployment. Economies of scope refer to cost savings realized when two related services can be offered together at lower cost than if the services were offered separately (Teece 1980; Panzar and Willig 1981; Tirole 1988). Multiservice contractors with a variety of technical skill sets may be able to achieve lower PV installation costs than contractors that focus exclusively on PV installation. Further, a single contractor installing PV at the same time as performing another related service might achieve a lower cost than is possible when offering the two services separately. For instance, a roofing contractor may be able to install a PV system at the time of roof replacement such that the total contract cost is less than the sum of the costs of installing the PV system and roof separately (Ardani et al. 2018). Some studies have found evidence of PV economies of scope, showing that PV prices tend to be lower for systems installed during new construction (Gillingham et al. 2016; Nemet et al. 2017).

California will soon provide a laboratory to test potential economies of scope in PV installation. In 2018, the California Energy Commission approved building code reforms that require all new homes below three stories high to install PV beginning in January 2020 (CEC 2018). The PV requirements could affect as many as 70,000 new homes in the first compliance year alone (Pyper 2018). The new policy raises many questions. Which companies will install the PV systems on new homes? Are home construction companies poised to incorporate PV systems into their projects on a large scale, or will they outsource the PV work to established PV installers? How will the building code requirement affect PV installation costs? Are there economies of scope in installing PV systems and rooftops at the same time, and how will these economies of scope affect PV prices?

In this report, we provide insight into these issues using a new data set based on data from the California Contractors State License Board (CSLB). We use the CSLB data to explore the technical backgrounds of PV installers and how these backgrounds affect PV markets in California specifically, with potential implications for U.S. markets broadly. In addition, we use PV price data compiled by Lawrence Berkeley National Laboratory to explore possible cost synergies between PV installation and related industries. 


\section{Contractor License Data}

The CSLB grants licenses to contractors that provide professional services such as home construction, roof replacement, and PV system installation. It grants different licenses for specific services. For instance, electrical contracting, roof replacement, and plumbing are permitted under three separate licenses. A contractor with any one of the following four licenses is permitted to install PV in California: electrical, general engineering, general building, and solar contracting (Table 1). Of the four licenses, the solar contractor license is the most restrictive, granting contractors permission to install PV and solar thermal systems, but not to offer related electrical or construction work. For the remainder of this report, we refer to these four licenses as PV-enabling licenses.

Table 1. PV-Enabling CSLB Licenses

\begin{tabular}{|c|c|}
\hline License & Description \\
\hline Electrical & $\begin{array}{l}\text { Licensed electricians can install systems "which generate, transmit, } \\
\text { transform or utilize electrical energy in any form or for any purpose." }\end{array}$ \\
\hline General engineering & $\begin{array}{l}\text { A general engineering contractor's primary business is "in connection } \\
\text { with fixed works requiring specialized engineering knowledge and } \\
\text { skill." Licensed general engineers are permitted to work on a wide } \\
\text { variety of projects. }\end{array}$ \\
\hline General building & $\begin{array}{l}\text { A general building contractor's primary business is "in connection with } \\
\text { any structure built, being built, or to be built, for the support, shelter, } \\
\text { and enclosure of persons, animals, chattels, or movable property of } \\
\text { any kind, requiring in its construction the use of at least two unrelated } \\
\text { building trades or crafts, or to do or superintend the whole or any part } \\
\text { thereof." }\end{array}$ \\
\hline Solar contractor & $\begin{array}{l}\text { A solar contractor "installs, modifies, maintains, and repairs thermal } \\
\text { and photovoltaic solar energy systems." Solar contractors are explicitly } \\
\text { prohibited from undertaking "building or construction trades, crafts, or } \\
\text { skills, except when required to install a thermal or photovoltaic solar } \\
\text { energy system." }\end{array}$ \\
\hline
\end{tabular}

Source: CSLB (2018b)

To obtain a license, a contractor must have at least one employee who passes an examination to certify their competency in a licensed service. Only those employees who have passed the examination are allowed to pull permits for the licensed activities. For example, a contractor could obtain an electrical license if at least one employee passes an examination to certify their ability to work with electrical equipment. Some contractors hold multiple licenses. Licensed employees are responsible for designing PV systems and obtaining the necessary permits, but PV systems may be physically installed by non-licensed employees.

A key assumption of our analyses is that a contractor's license portfolio indicates the services offered by the contractor. For instance, if a contractor holds electrical and roofing licenses, we assume that the contractor offers both electrical and roofing services. This assumption allows us to infer the types of related services offered by PV installers. The validity of this assumption rests on the observation that relatively few contractors hold multiple licenses (Figure 1). According to CSLB data, only about $16 \%$ of contractors hold multiple licenses, and about $99 \%$ of contractors hold fewer than four licenses. 


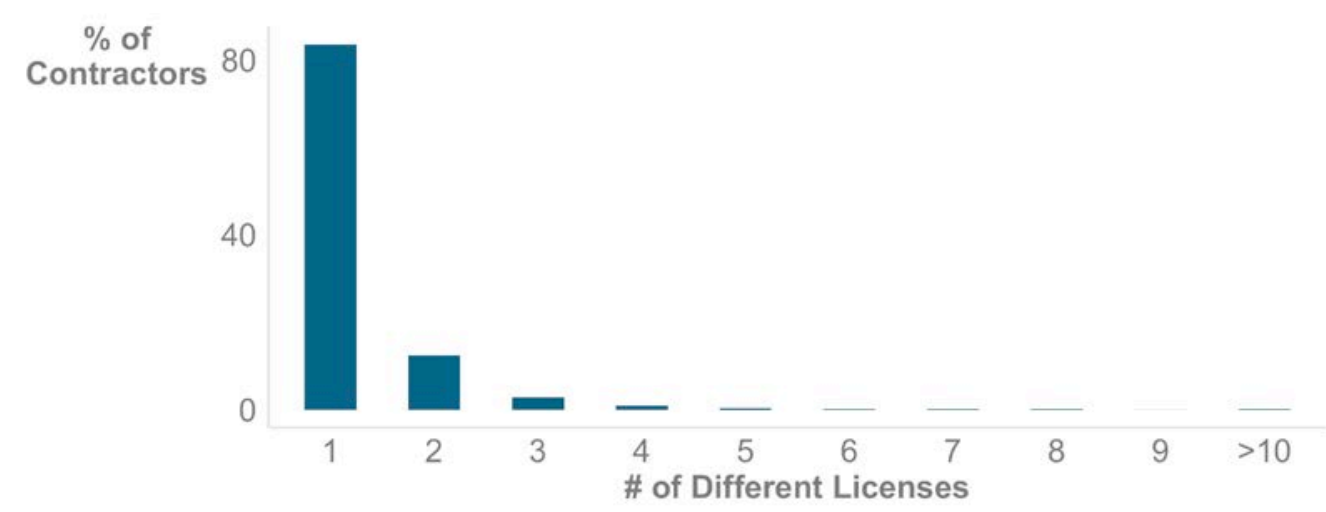

Figure 1. Distribution of the number of different licenses held by contractors

That contractors tend to hold relatively few licenses is likely attributable to various requirements and transaction costs in the license application process. To apply for a license in California, a contractor must have at least one "qualifying individual" with four years of relevant experience in the field in the previous decade (CSLB 2017). Relevant experience may include training in an accredited school. The qualifying individual must take an examination for the specific license as well as a standard business and law examination. Licenses must be renewed every two to four years. Each license issuance entails around \$500 in processing fees, and typical total processing times for adding a new license are around 100 days (CSLB 2017). ${ }^{1}$ As a result of these requirements and costs, contractors have incentives to develop an efficient license portfolio comprising only licenses for the services they actually offer.

We obtained contractor license data from the CSLB. The full CSLB data set consists of 794,695 records on 704,035 contractors dating back to 1929 (CSLB 2018a). ${ }^{2}$ Each entry includes the types of licenses held by each contractor. To restrict the temporal scope of the data, we eliminate contractors whose licenses expired before January 1, 2010. ${ }^{3}$ The CSLB data set does not specify which contractors have installed PV. To identify PV installers, we used contractor names to match records from the CSLB to records from Lawrence Berkeley National Laboratory's Tracking the Sun data set (Barbose and Darghouth 2017). Of the roughly 5,500 installers that installed at least one PV system in California from 2010 to 2016, we successfully matched 2,029 to a contractor name in the CSLB data set. ${ }^{4}$ The group of matched installers collectively installed 378,624 systems from 2010 to 2016, representing about two thirds of all systems installed in the state over this period.

\footnotetext{
${ }^{1}$ Processing time is based on a median of 96 days for additional licenses issued to contractors that already hold at least one other license.

${ }^{2}$ The subset of contractor license data used for this study is publicly available at [will be posted]. The full CSLB data set is available for purchase through the CSLB at http://www.cslb.ca.gov/About_Us/Library/Forms_And_Applications.aspx.

${ }^{3}$ The data set includes the original issue date of the contractor's first license and expiration date (if applicable) if the last license held by the installer. However, the data set does not specify which licenses were obtained on which dates. For instance, if a contractor holds an electrical and a solar license, it is possible that the contractor began as a licensed electrician and obtained the solar license later or vice versa.

${ }^{4}$ The large number of unmatched installers is due to vague or inconsistent names reported by installers or customers to PV incentive programs. For instance, an installer name in Tracking the Sun may be reported as "J. Smith" or "J Electric," which is too vague to be precisely matched to a contractor in the CSLB. The installer name data cleaning process is described in O'Shaughnessy (2018).
} 


\section{License, Scale, and Business-Model Characteristics of PV Installers}

Electrical licenses are the most common license in the PV installer license portfolio, followed closely by general building licenses (Figure 2). The prevalence of electrical licenses among PV installers reflects the close ties between these two industries. According to one survey, about $40 \%$ of PV installers continue to offer electrical services (EnergySage 2018), which corresponds well with the CSLB data showing that about $53 \%$ of installers hold electrical licenses. The fact that only about $21 \%$ of PV installers hold a solar contractor license may reflect the lower utility of the license. For instance, a licensed electrician can install a PV system, but a licensed solar contractor cannot perform electrical work unrelated to PV installation.

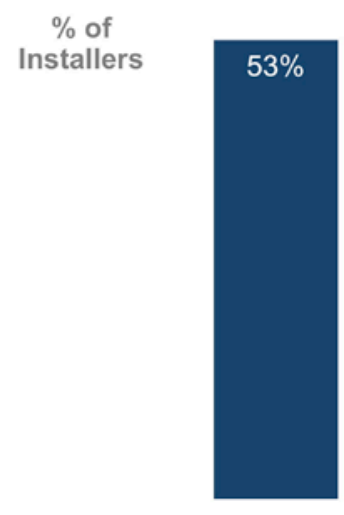

Electrical

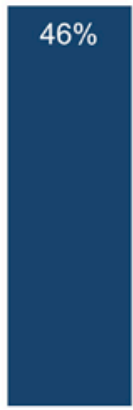

General Building

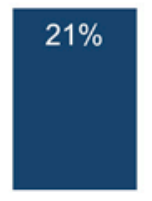

Solar
$7 \%$

General Engineer

Figure 2. Percentage of installers in the study data set that hold different PV-enabling licenses

Note: Percentages in figures do not add up to and may exceed $100 \%$ because installers may hold multiple licenses

Figure 3 illustrates the distribution of PV installer license portfolios. Most installers hold a single PV-enabling license, most commonly an electrical license (35\%) or a general building license $(25 \%)$. About $9 \%$ of installers hold only a solar contractor license, and about $25 \%$ hold multiple PV-enabling licenses. Interestingly, about 5\% of installers do not hold any of the PV-enabling licenses (though they are licensed in other professions such as roofing). In these cases, the installer most likely collaborated with another contractor that held a PV-enabling license to pull the solar permit. 


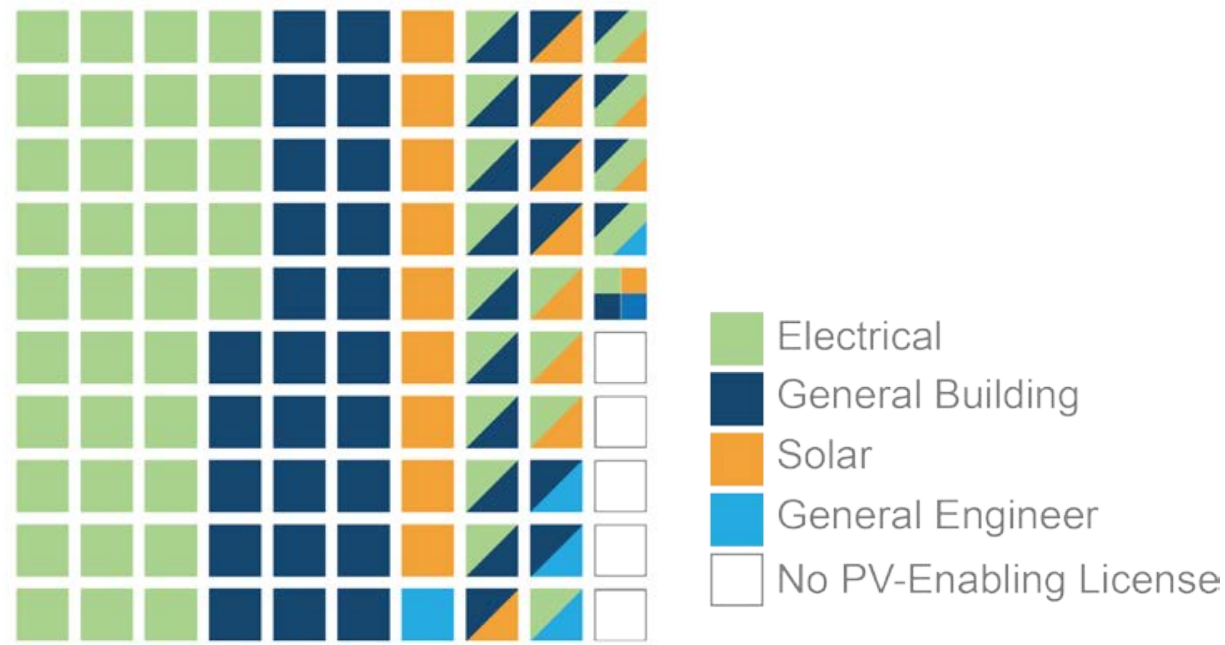

Figure 3. Combinations of PV-enabling licenses held by installers

About $20 \%$ of installers hold professional licenses other than the four PV-enabling licenses (Figure 4). About 9\% of installers hold an HVAC license, about 4\% hold a plumbing license, and about $4 \%$ hold a roofing license. Of the non-PV-enabling licenses, roofing licenses are particularly relevant to this study given potential synergies between roofing and rooftop PV installation (Ardani et al. 2018). For this reason, roofing licenses are included in subsequent analyses, although roofing licenses alone do not permit contractors to install PV, and licensed roofers without at least one PV-enabling license would need to work with another licensed contractor to pull permits for PV installations.

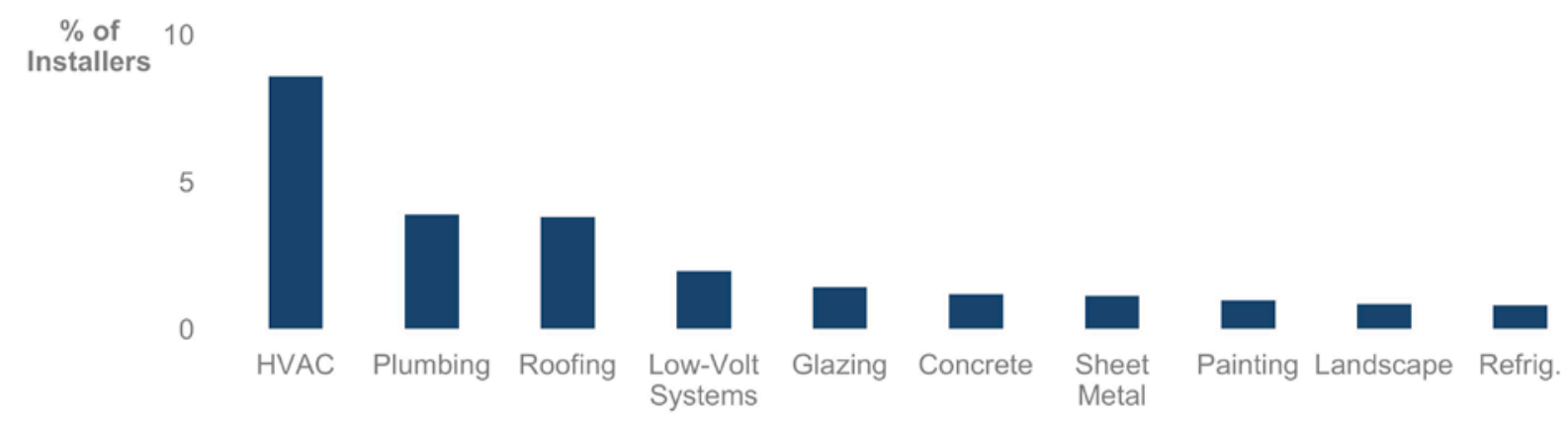

Figure 4. Most common non-PV-enabling licenses held by PV installers

Statistics by proportion of systems installed provide additional insights. Although about 53\% of installers are licensed electricians, they install a disproportionately large share of PV systems (about 80\%) (Figure 5). The disparity stems from the fact that most systems were installed by established installers that tend to hold multiple licenses. The difference is particularly stark in the case of roofing: only about $4 \%$ of installers are licensed roofers, but about $45 \%$ of systems were installed by an installer with a roofing license. This result is driven largely, but not exclusively, by the high-volume installer Tesla (formerly SolarCity), which holds all four PV-enabling licenses as well as a roofing license. 


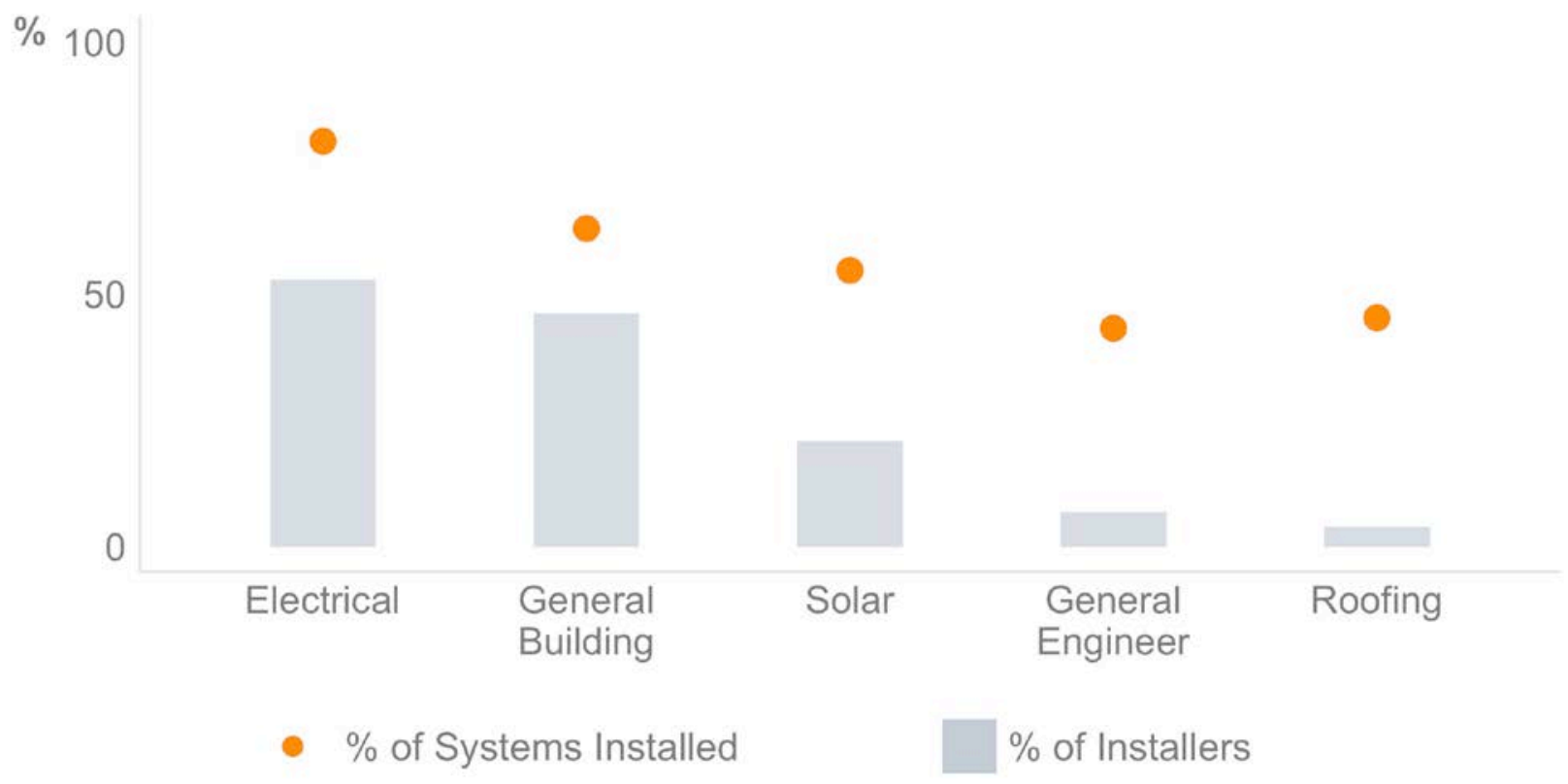

Figure 5. Percentage of PV systems installed and percentage of installers by license type

To examine the relationship between installer scale and licenses more directly, Figure 6 plots the percentage of installers that hold different licenses at four different installer scales, which we refer to as singletons, dabblers, mid-scale, and established installers. Singletons installed a single PV system during the study period, dabblers installed one or fewer systems per month, mid-scale installers installed 2-10 systems per month, and established installers installed more than 10 systems per month. Installer scale does not appear to affect whether installers hold an electrical or general engineering license, but interesting differences emerge for solar, general building, and roofing licenses.

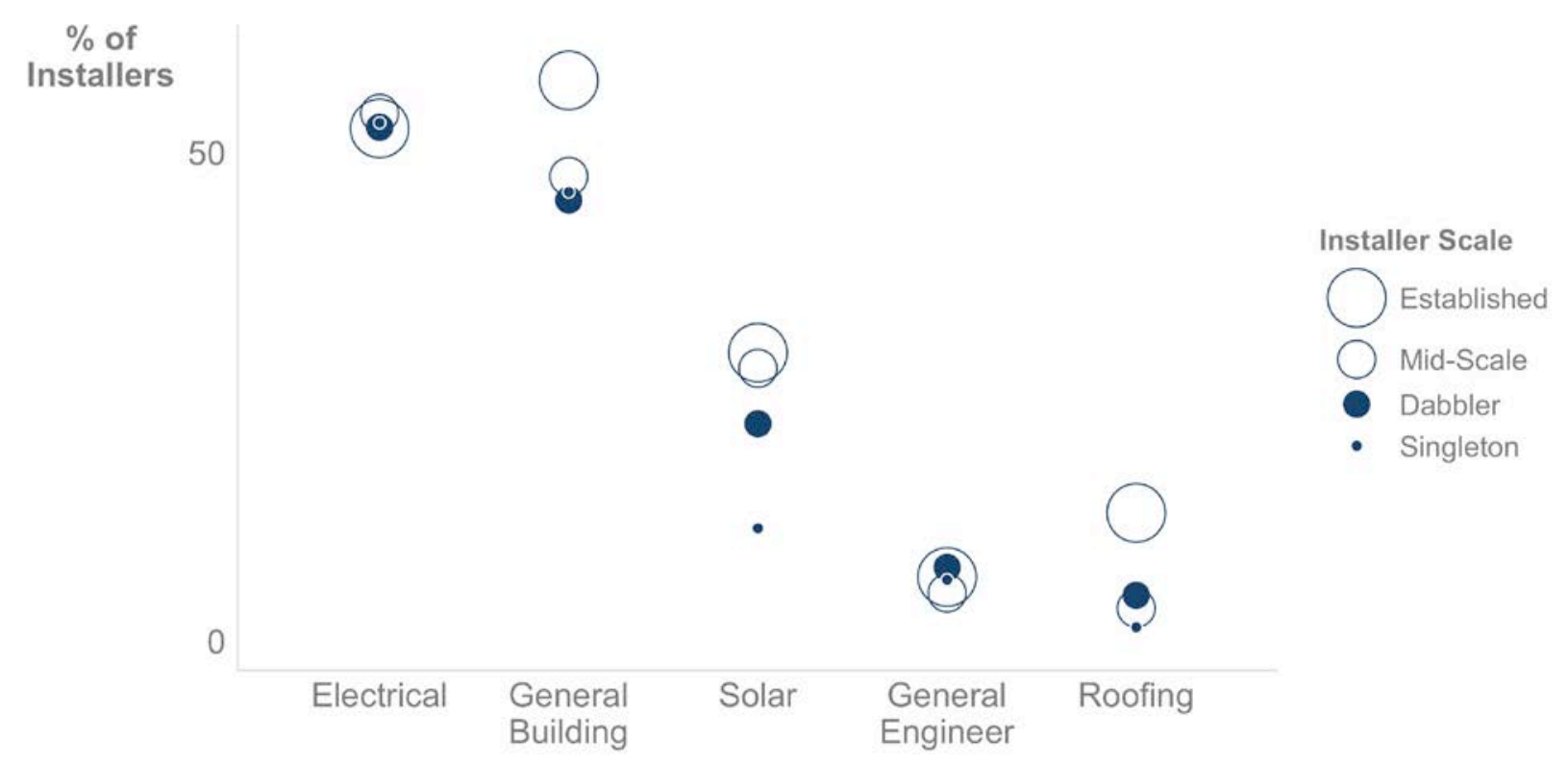

Figure 6. Percentage of PV installers by installer scale and license type 
Mid-scale and established installers are about $49 \%$ more likely to hold solar contractor licenses than are singletons and dabblers ( $\mathrm{t}=3.9)$, suggesting that installers have incentives to obtain the solar contractor license at larger scales of PV installation. Obtaining the solar contractor license might reduce labor costs. Electrician labor is generally more expensive than other forms of installer labor (Seel et al. 2014; BLS 2018). Established installers may be able to reduce labor costs by shifting more responsibilities to lower-cost solar contractors and relying less on highercost electrician labor. For instance, established installers may task solar contractors with system design for most systems, while limiting electrician labor to complex systems or installations with batteries. Another possibility is that solar contractor licenses can be used for promotional purposes, such as adding the words "licensed solar contractor" in promotional materials.

Established installers are more likely to hold licenses other than the solar contractor license, in part because established installers are more likely to hold multiple licenses (Figure 7). In particular, established PV installers are about $36 \%$ more likely to hold general building and roofing licenses than are other installers $(\mathrm{t}=2.7)$. In contrast, dabblers are more likely to hold a single license, particularly an electrical license. This outcome may be partially driven by firm scale: larger contracting firms with more employees may be better positioned to obtain multiple licenses. The outcome also suggests that dabblers tend to specialize in a practice while established installers tend to offer multiple services.

Established Installers

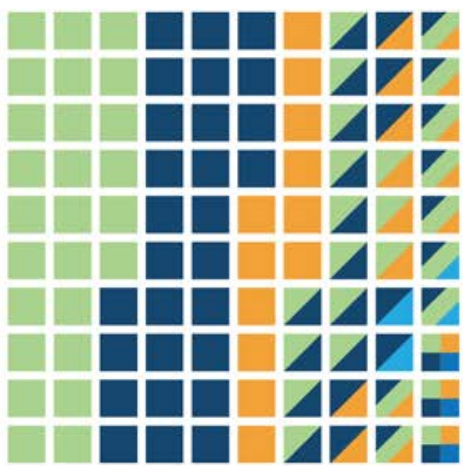

Dabblers

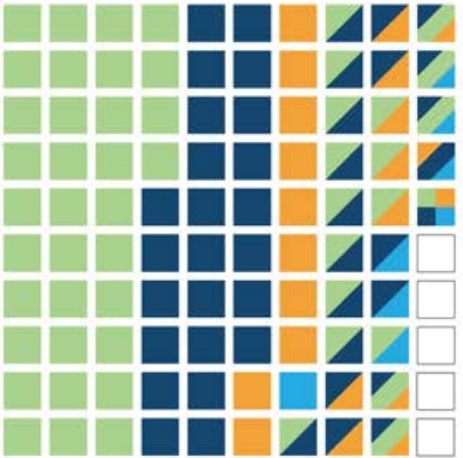

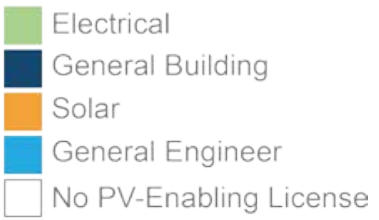

Figure 7.Combinations of PV-enabling licenses held by established installers and dabblers

Finally, established installers are also about 2.6 times more likely to install systems during new construction ( $\mathrm{t}=37.5$ ) (Figure 7), providing further evidence that established installers are multiservice firms. Together, these results suggest that established installers are more frequently incorporating construction and roofing services into their business models. Interestingly, singletons are also associated with a relatively large percentage of systems installed during new construction. These cases may represent situations where a construction or roofing company installed PV on a single home. 


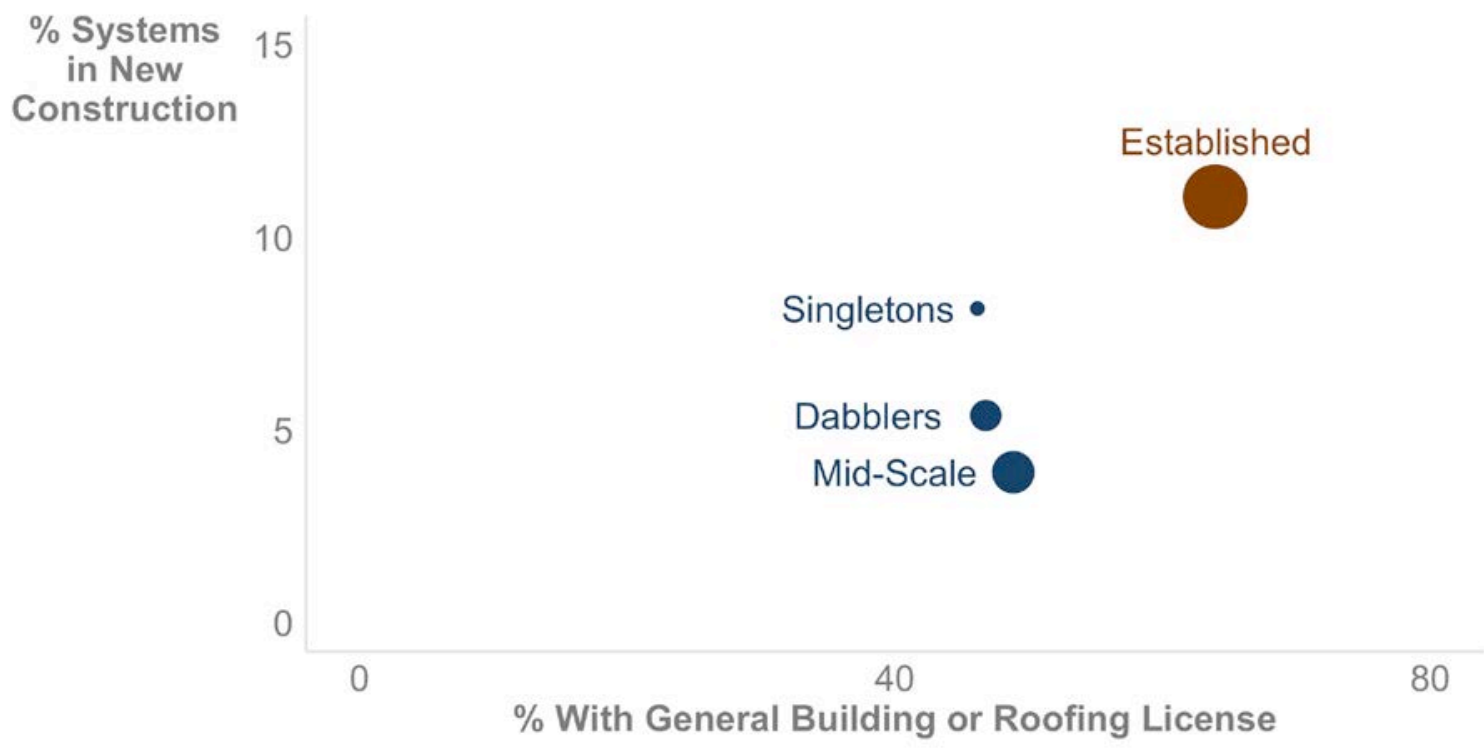

Figure 8. Correlation between percentage of PV systems installed on new construction and percentage of installers with general building or roofing licenses, by installer scale 


\section{Effects of License Portfolios on Customer-Owned Residential PV Prices}

To explore the relationships between installer license portfolios and installed PV prices, we use the Tracking the Sun-based price data set developed and described in O'Shaughnessy (2018a). The data set is limited to customer-owned residential PV systems and excludes systems installed with batteries, thin film, tracking systems, and building-integrated PV. After matching installer names with contractor names in the CSLB data, the price data set represents 98,679 systems installed in California from 2010 to 2016 . All prices are in 2016 dollars normalized by system size $(\$ / \mathrm{W})$. Prices refer to the full installed price paid by the customer, therefore prices include all system costs (e.g., hardware, soft costs) plus the installer's margin. All else equal, installed prices correlate with costs, so that lower prices provide evidence of lower costs (e.g., through economies of scope).

\subsection{Descriptive Price Statistics}

Installed PV prices fell year over year throughout the study period for installers across license types (Figure 8). Prices of PV systems from installers with solar contractor licenses were relatively high throughout the study period, while systems installed by licensed roofers and general engineers were relatively low.

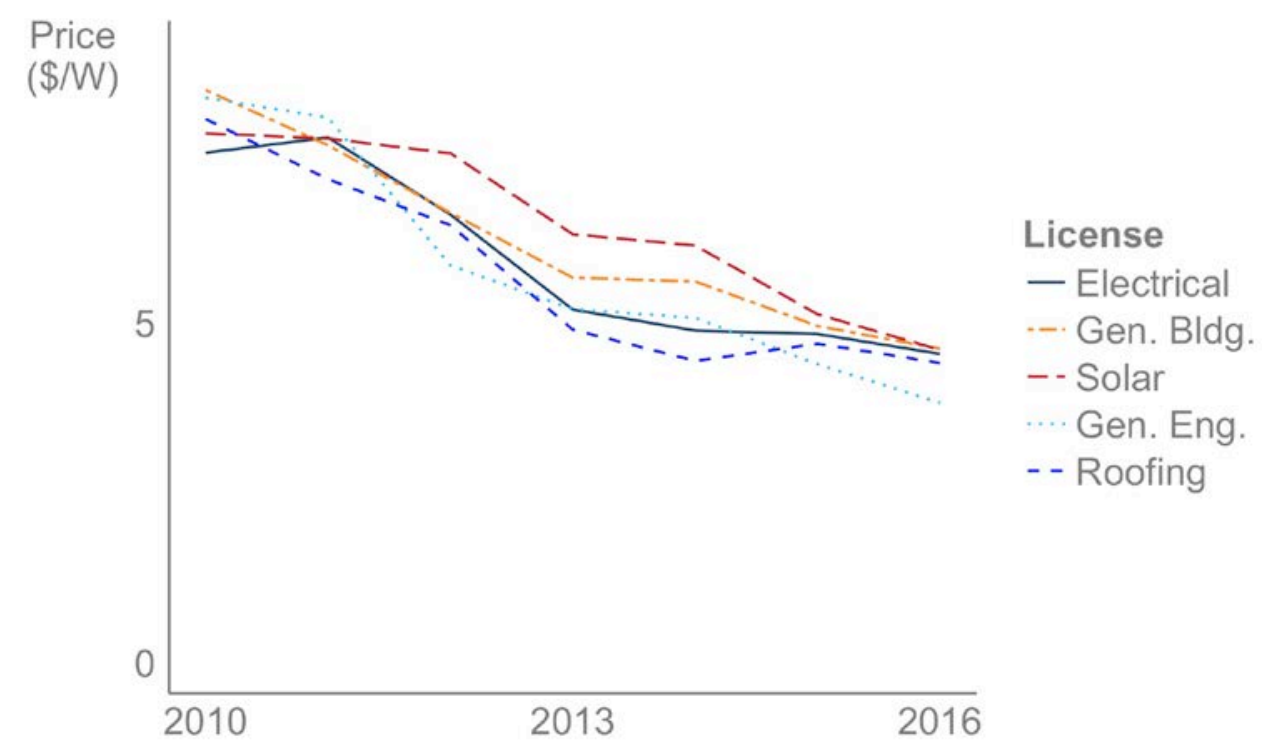

Figure 9. Annual mean installed PV prices by license held, 2010-2016

Note: License categories are not mutually exclusive. Installers with multiple licenses are reflected in multiple lines.

To reduce the influence of the temporal variation in prices illustrated in Figure 8, we present the following analyses in terms of de-meaned prices. For each system, we subtract the mean price of 
all systems installed in that year and then re-center the system price on the mean price in 2016 $(\$ 4.57 / \mathrm{W})$, so that all years have roughly the same mean price. ${ }^{5}$

Figure 9 illustrates de-meaned price distributions by license. Consistent with the year-over-year trends, prices from installers with solar contractor licenses were higher on average, while prices from those with general engineer and roofing licenses were lower on average.

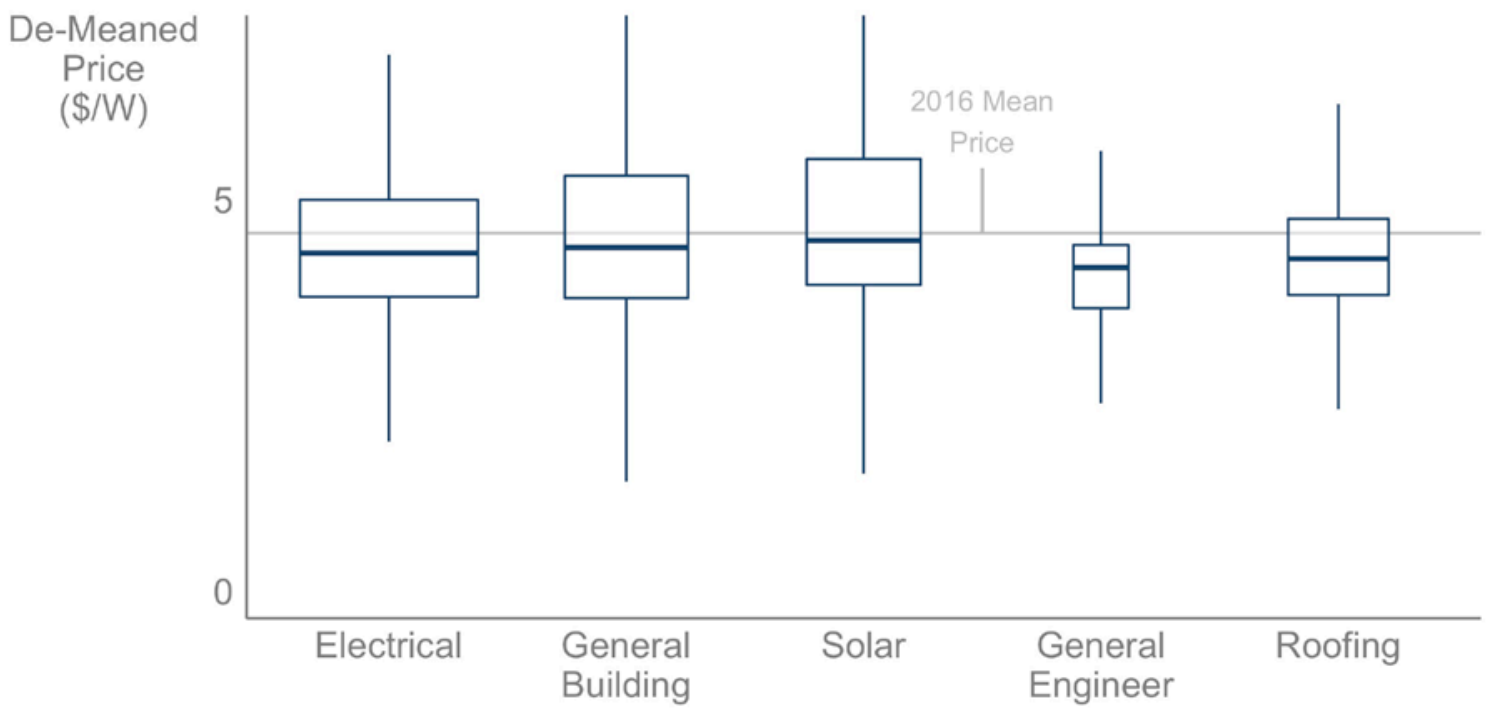

Figure 10. De-meaned installed PV price distributions by license held, 2010-2016

Note: Boxes represent inter-quartile ranges $\left(25^{\text {th }}\right.$ to $75^{\text {th }}$ percentile), lines in boxes represent medians, outlier prices excluded

In Section 3, we show that singletons and dabblers are less likely to hold the solar contractor license than are mid-scale and established installers, supporting the hypothesis that small-scale installers are more likely to be from related-service industries and treat PV installation as a side business. O'Shaughnessy (2018a) shows that singletons and dabblers are also associated with lower PV prices, on average, than mid-scale installers are. These small-scale installers might be able to offer lower prices because they recoup certain installation costs through revenues from their primary lines of business. Further, they may incur lower customer-acquisition costs by tapping their preexisting customer bases for PV customers or low-cost referrals. They may also be able to suggest installing a PV system to an existing customer when they are in the customer's home doing some other work.

Figure 10 explores these hypotheses by comparing PV prices at different installer scales for installers with and without the solar contractor license. We assume that singletons and dabblers without the solar contractor license generally represent companies that install PV as a side business. Consistent with previous findings, singletons and dabblers are associated with lower prices, on average, than mid-scale installers. Further, dabblers without the solar contractor license are associated with the lowest prices across the groupings. The mean price of a system installed by a dabbler without the solar contractor license is $\$ 4.18 / \mathrm{W}$ (de-meaned), about $9 \%$

${ }^{5} d m p_{i y}=4.57+p_{i y}-\bar{p}_{y}$, where $d m p_{i y}$ is the de-meaned price of system $i$ installed in year $y, p_{i y}$ is the actual system price, and $\bar{p}_{y}$ is the mean price in year $y$. 
lower than other prices on average ( $\mathrm{t}=22.3)$. These data provide further support for the hypothesis that PV dabblers can reduce costs by incorporating PV installation into preexisting businesses. Similarly, the mean price of a system installed by an established installer without the solar contractor license is about $4 \%$ lower than other prices on average $(t=18.7)$, suggesting that established installers that offer other services also realize economies of scope.

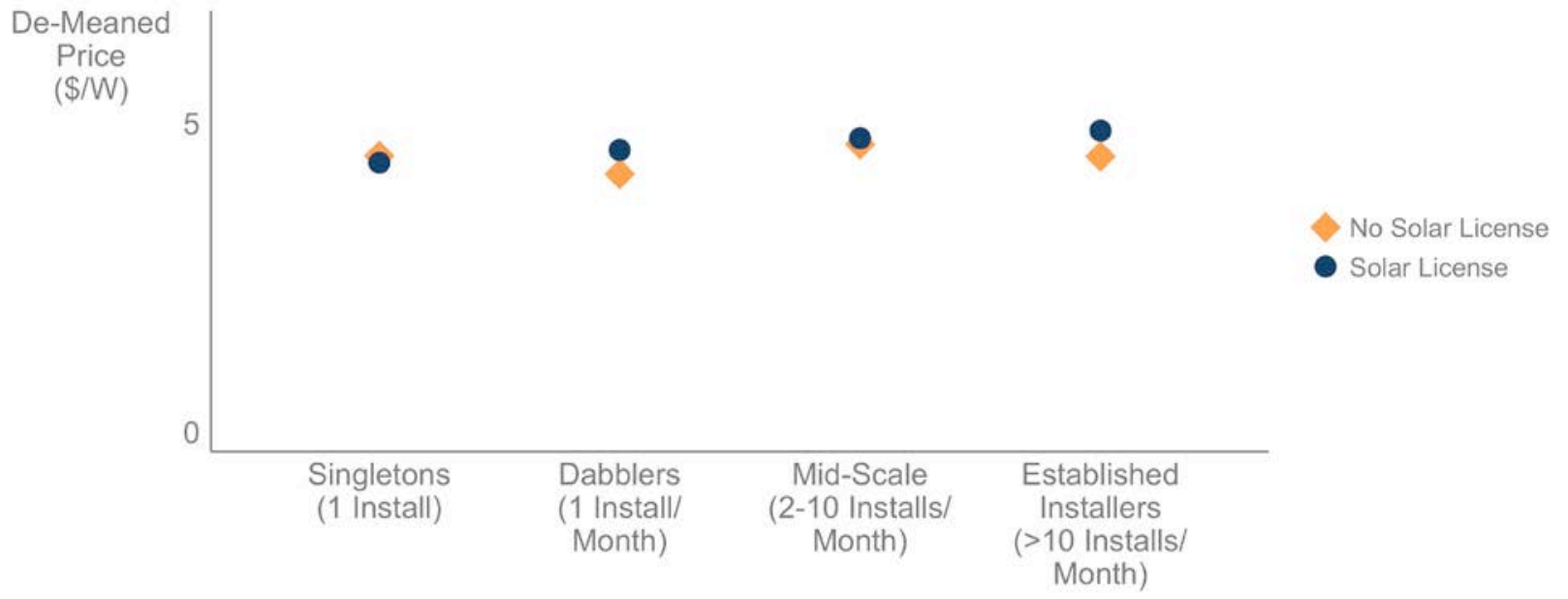

Figure 11. De-meaned average installed PV prices by installer scale for installers with and without a solar contractor license

Previous studies find that PV system prices are lower when PV is installed during new construction (Gillingham et al. 2016; Nemet et al. 2017). Lower PV prices for new-construction systems may reflect economies of scope: the total cost of new construction and PV installation may be lower when the two activities are conducted at the same time rather than separately. If so, installers with construction-related licenses (e.g., general building, roofing) might be able to install new-construction PV systems more efficiently than installers without these skill sets can. Figure 11 explores this hypothesis by plotting mean prices for retrofit PV systems and systems installed during new construction by license held. New-construction systems are about $20 \%$ lower-priced than retrofits in general $(\mathrm{t}=24.4) .{ }^{6}$ The lowest-priced systems across all categories are new-construction systems installed by licensed roofers. This result accords with the economies-of-scope hypothesis: roofers may have unique skill sets that enable them to install PV systems more efficiently at the time of new construction than installers with other technical backgrounds. In contrast, prices for systems installed by solar contractors tend to be relatively high and exhibit little variation between retrofits and new construction.

\footnotetext{
${ }^{6}$ An increasing number of new homes are built with "solar-ready" construction, which could lower the costs of retrofit installations and reduce the price disparity between new construction and retrofits. The potential cost savings of solar-ready construction are an area for further research.
} 


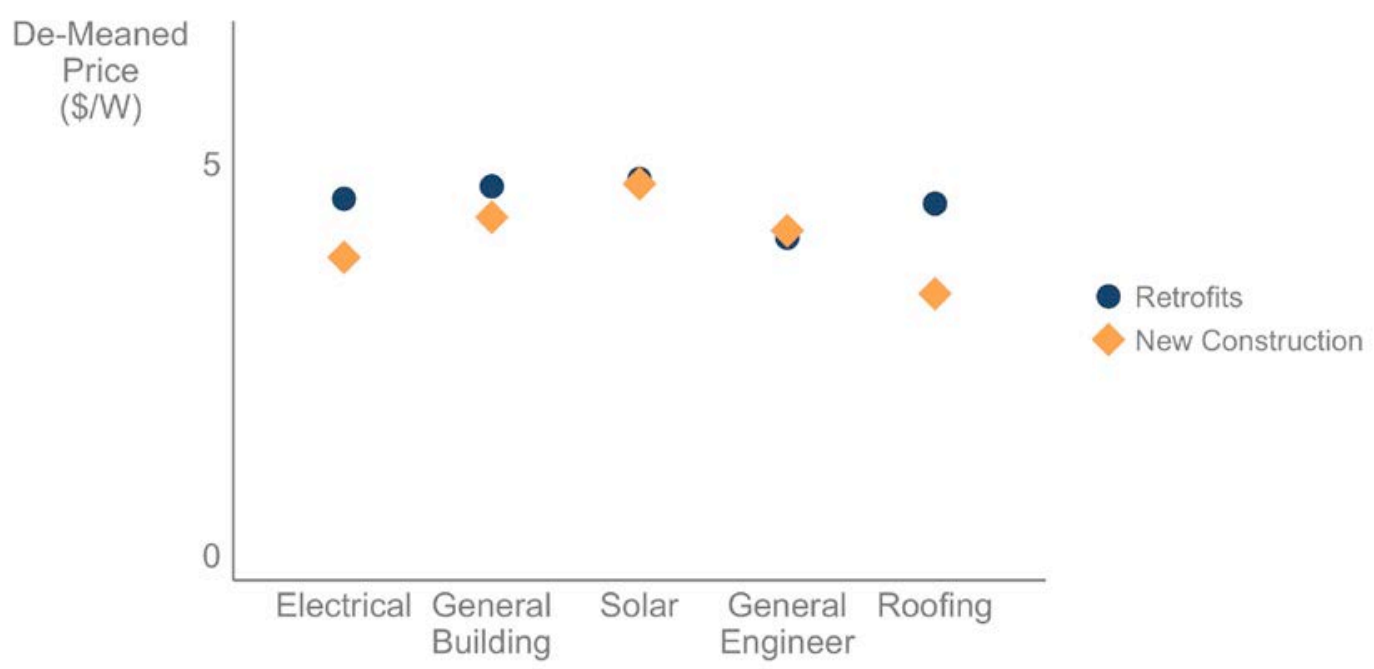

Figure 12. De-meaned average installed PV prices for retrofits and new-construction systems by license held

\subsection{Econometric Model}

To ensure the relationships described in Section 4.1 are not spurious, it is necessary to control for additional factors that may affect PV prices and correlate with the licenses held by installers. We test the effects of licenses on prices through the two linear models:

$$
\begin{gathered}
p=E L \alpha_{1}+G B \alpha_{2}+S O L \alpha_{3}+G E \alpha_{4}+R F \alpha_{5}+n c \phi+X \beta+\varepsilon \\
p=E L \gamma_{1}+E L n c \gamma_{2}+G B \gamma_{3}+G B n c \gamma_{4}+S O L \gamma_{5}+S O L n c \gamma_{6}+G E \gamma_{7} \\
+G E n c \gamma_{8}+R F \gamma_{9}+R F n c \gamma_{10}+\boldsymbol{X} \beta+\varepsilon
\end{gathered}
$$

Where $p$ is the installed price of PV measured in 2016 dollars $(\$ / \mathrm{W})$, the variables $E L, G B, S O L$, $G E$, and $R F$ are dummy variables for the five contractor licenses (electrical, general building, solar contractor, general engineer, roofing), $n c$ is a dummy variable for whether the system was installed during new construction, $\boldsymbol{X}$ is a matrix of control variables, $\alpha, \phi$, and $\beta$ are coefficients estimated by the model, and $\varepsilon$ is an error term. The coefficients $\alpha_{1}-\alpha_{5}$ estimate the difference in the mean price from installers that hold each license when controlling for the other factors in the model. The control variables in $\boldsymbol{X}$ are based on the models previously developed in Gillingham et al. (2016) and O'Shaughnessy (2018). See the appendix for a list of the control variables, and O'Shaughnessy (2018) for a complete discussion of the control variables and the methods used to construct them. Utility fixed effects are used to control for unobserved geographic variation across utility service territories. Quarterly fixed effects are used to control for unobserved variation over time. Model (2) estimates separate effects by contractor license for retrofits and new-construction systems through interaction terms. For instance, $\gamma_{1}$ estimates the average price difference for electricians for retrofit systems, and $\gamma_{2}$ estimates the average price difference for electricians for new-construction systems. 
Table 2 displays the results of the two models. The license coefficients in Model (1) can be interpreted as the shift in average system price associated with holding each license, all else equal. For example, Model (1) shows that prices for systems installed by electricians tend to be priced higher by $\$ 0.16 / \mathrm{W}$, all else being equal. The license coefficients in Model (2) can be interpreted as the shift in average system price associated with holding each license for retrofit systems. The sum of the coefficients for the licenses and the interaction terms can be interpreted as the shift in average system prices for each license for new-construction systems, as depicted in Figure 12. For example, Model (2) shows that prices for retrofits installed by electricians tend to be $\$ 0.16 / \mathrm{W}$ higher, and that prices for new-construction systems tend to be $\$ 0.09 / \mathrm{W}$ higher $(0.16-0.07=0.09)$. The full regression results, including coefficients for the control variables, are provided in the appendix.

Table 2. Regression Results, $\mathrm{Y}=$ Price (2016\$/W)

Heteroskedasticity robust t-statistics based on utility-clustered standard errors in parentheses

\begin{tabular}{lcc}
\hline & $(1)$ & $(2)$ \\
\hline Electrical & 0.16 & 0.16 \\
Electrical x New Construction & $(14.17)^{\mathrm{a}}$ & $(14.07)^{\mathrm{a}}$ \\
& & -0.07 \\
General Building & 0.05 & $(0.93)$ \\
General Building x New Construction & $(4.23)^{\mathrm{a}}$ & 0.04 \\
Solar Contractor & & $(3.48)^{\mathrm{a}}$ \\
& & -0.36 \\
Solar Contractor x New Construction & 0.24 & $(1.96)^{\mathrm{b}}$ \\
General Engineer & $(19.13)^{\mathrm{a}}$ & 0.23 \\
& & $(17.94)^{\mathrm{a}}$ \\
General Engineer x New Construction & & 0.13 \\
& -0.26 & $(0.78)^{\mathrm{a}}$ \\
Roofing & $(9.15)^{\mathrm{a}}$ & -0.25 \\
& & $(8.70)^{\mathrm{a}}$ \\
Roofing x New Construction & & 0.26 \\
New Construction & -0.07 & $(1.05)^{2}$ \\
& $(4.80)^{\mathrm{a}}$ & -0.001 \\
& & $(0.09)^{2}$ \\
\end{tabular}

${ }^{\mathrm{a}}$ Statistically significant at $\mathrm{p}<0.01,{ }^{\mathrm{b}} \mathrm{p}<0.05$

Focusing first on Model (1), the results are generally consistent with the descriptive statistics: systems installed by licensed general engineers and roofers tend to be lower priced, on average, after controlling for the other regression variables. Conversely, licensed electricians, solar contractors, and general builders are associated with higher prices. The higher prices associated with electrician-installed systems may be attributable to the relatively higher rates for electrical labor. However, it is unclear why installers with the solar contractor license are associated with higher prices. This result may indicate some inefficiencies associated with installers with the solar contractor license, or simply that installers with solar contractor licenses are less likely to benefit from the economies of scope associated with other licenses. Alternatively, it is possible that licensed solar contractors exercise some market power, such as through branding themselves 
as professional solar contractors, that could allow them to bid higher prices. The coefficient on new construction in Model (1) suggests that new-construction systems are about $\$ 2.17 / \mathrm{W}$ lower priced, on average, than retrofit systems.

Moving to Model (2), Figure 12 depicts the predicted effects of holding the different licenses on retrofit and new-construction systems. Licensed electricians and solar contractors are associated with higher prices for both retrofits and new-construction systems. Interestingly, licensed general building contractors are associated with higher prices for retrofits but lower prices for newconstruction systems, while the opposite is true for general engineers. The starkest effect from Model (2) is the significant price reduction associated with new-construction systems installed by licensed roofers. The model suggests that new-construction systems installed by roofers are about $\$ 2.00 / \mathrm{W}$ lower priced than other systems, on average.

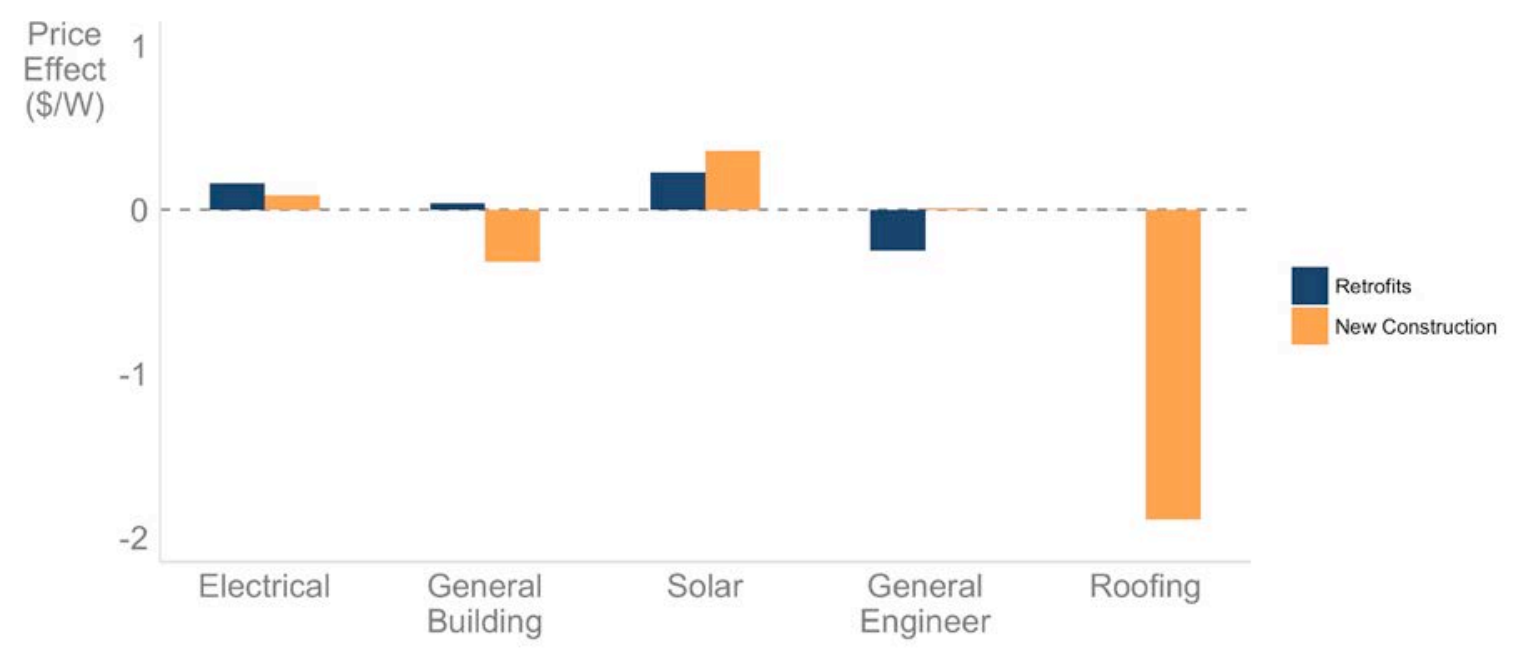

Figure 13. Effects of holding different licenses on installed PV prices for retrofits and newconstruction systems, based on regression results

The results of the regression models provide convincing evidence for economies of scope in PV installation, especially for new-construction systems installed by licensed roofers. Some limitations should be noted. First, Gillingham et al. (2016) estimate price reductions from new construction of about $\$ 0.70 / \mathrm{W}$, about three times lower than the $\$ 2.17 / \mathrm{W}$ coefficient estimated in Model (1) of this study. The disparity may stem from the fact that only about 3\% of systems in the data set were installed in new construction, so the effect is based on a relatively small sample of about 3,300 systems. There may be spurious factors associated with this subset of the data that could bias the results and yield an overestimate of the potential price reduction associated with new-construction systems. Second, the subset of the data representing new-construction systems installed by licensed roofers is even smaller. About 240 installers in the data set installed newconstruction systems, of which 11 were licensed roofers that installed 21,258 systems in the data set. Again, there may be spurious factors associated with this subset of installers that could yield an overestimate of the price reduction associated with roofer-installed new-construction systems. For instance, we have not controlled for other quality and performance variables that could affect prices. Therefore, the magnitude of the coefficients should be interpreted with some caution, though the signs of the effects are fully consistent with theoretical expectations based on economies of scope. 


\section{Discussion and Conclusion}

The CSLB data illustrate the variety of technical backgrounds brought to bear in the PV installation industry. Nearly $90 \%$ of PV installers hold some license other than the solar contractor license. The data strongly suggest that the PV installation industry has emerged from and continues to be interwoven with other preexisting industries.

Still, the PV installation industry remains smaller than those of related industries, which equates to a large untapped pool of businesses with the potential to install PV efficiently and at scale. We estimate that, of the roughly 230,000 contractors that could have installed a PV system from 2010 to 2016 in California, only about 2\% actually installed PV. More than $90 \%$ of licensed electricians, general engineers, roofers (who need an additional license to install PV), and general building contractors in California did not install PV from 2010 to 2016 (Figure 13). About two-thirds of contractors with a solar contractor license installed PV. The remaining third could represent contractors that install rooftop solar thermal systems, which is permitted by the same license, or contractors that obtained the solar contractor license but did not make a successful bid during the study period.

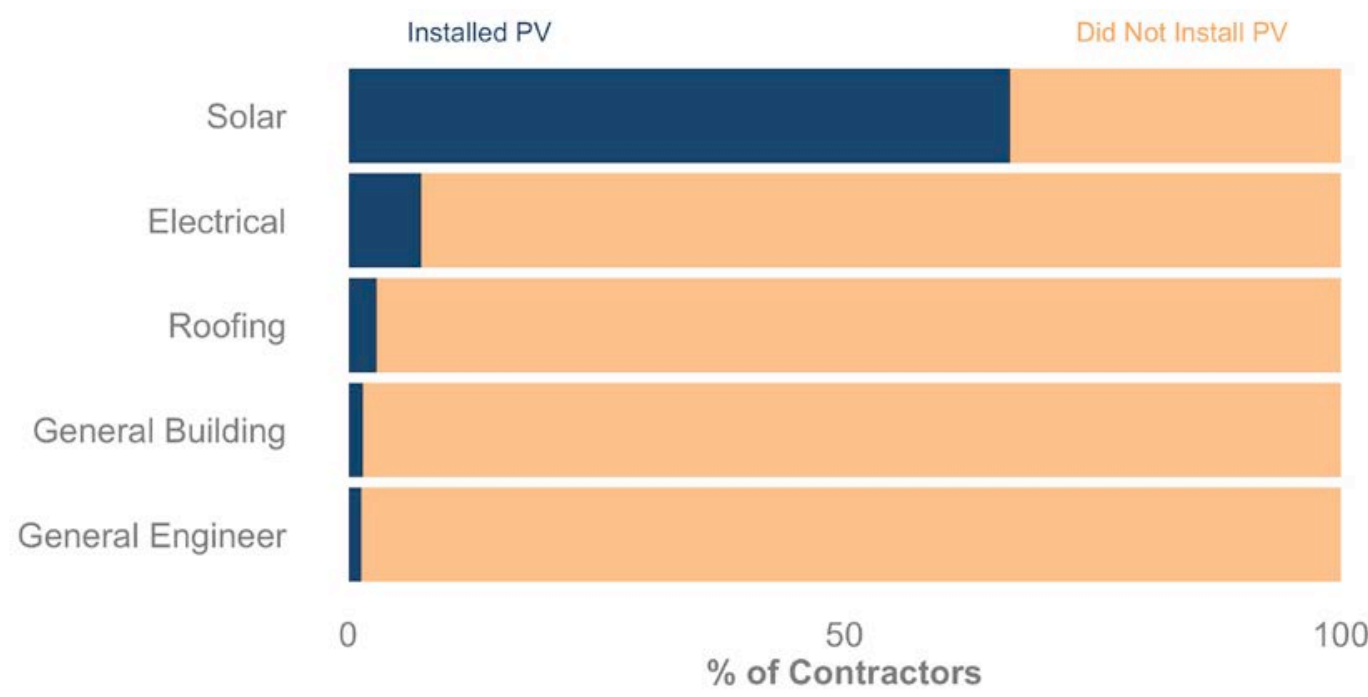

Figure 14. Percentages of licensed contractors that either installed PV or did not install PV in California, 2010-2016

Four key policy implications emerge from our analysis of the CSLB data:

- $\quad$ The PV installation industry is integrated with related-service industries. The CSLB data clearly show the linkages between PV installation and related services such as electrical contracting, general construction, and roofing. Policymakers may be able to leverage these linkages by supporting programs that help contractors incorporate PV installation into their business models.

- Small-scale installers may improve PV market efficiency through economies of scope. The CSLB data support the hypothesis that many small-scale PV installers represent companies from related-service industries that occasionally install PV. The data also provide further support for the hypothesis that such installers can offer lower prices, possibly because they can recoup costs through revenues in their primary lines of 
business and may face lower customer-acquisition costs owing to preexisting customer relationships. These findings suggest that, although large-scale installation may be efficient because of returns to installer experience, small-scale installation may also yield installation cost reductions. Policymakers may be able to facilitate PV dabbling by removing barriers to entry such as overly restrictive licensing or certification requirements.

- Large-scale, established installers are integrating multiple services into their business models. Established installers are more likely than other installers to hold multiple licenses, including general building and roofing licenses. Further, established installers are more likely to install systems during new construction. Established installers may be in the best position to leverage economies of scope in terms of installing PV during new home construction or roof replacement. Policymakers could leverage these economies of scope by implementing policies that support either installer scaling or PV installer training in related fields such as roofing.

- Multiservice contractors are associated with lower installed PV prices, especially for $n e w$-construction systems. Installers with general engineering and roofing licenses are associated with lower prices, possibly because these installers rely less on high-cost electrician labor. Further, the regression results provide strong evidence of economies of scope in PV installation during new construction, especially if the installer is a licensed roofer. Policymakers could leverage these economies of scope by implementing policies that incentivize PV installation during new construction or roof replacement.

Our analysis indicates that the integration of PV installation with other construction activities may yield significant PV price reductions. California's new building code mandating that PV be installed on all new homes will provide a useful testing ground for this hypothesis. The newconstruction share of the California PV market will grow significantly as a result of the new homes policy. Careful data collection and analysis could yield additional insights into economies of scope in PV installation and how leveraging different technical backgrounds could provide opportunities for further PV price reductions. Future work could explore these data from the California new construction market to understand how policymakers could further tap PV economies of scope. 


\section{References}

Ardani, K., J. Cook, R. Fu, and R. Margolis. 2018. Cost-Reduction Roadmap for Residential Solar Photovoltaics (PV), 2017-2030. NREL/TP-6A20-70748. Golden, CO: NREL.

CEC (California Energy Commission). 2018. 2019 Title 24, Part 6, Building Energy Efficiency Standards.

CSLB (Contractors State License Board). 2017. California Contractors License Law \& Reference Book. 2017 Edition. Charlottesville, VA: LexisNexis.

CSLB (Contractors State License Board). 2018a. License Master File. Obtained May 2, 2018.

CSLB. 2018b. Licensing Classifications. Accessed May 23, 2018. http://www.cslb.ca.gov/About_Us/Library/Licensing_Classifications/.

EnergySage. 2018. Solar Installer Survey 2017 Results. EnergySage.

Gillingham, K., H. Deng, R. Wiser, N. R. Darghouth, G. Nemet, G. Barbose, V. Rai and C. G. Dong. 2016. "Deconstructing Solar Photovoltaic Pricing: The Role of Market Structure, Technology, and Policy.” Energy Journal 37(3): 231-250.

Nemet, G., E. O'Shaughnessy, R. Wiser, N. Darghouth, G. Barbose, K. Gillingham and V. Rai (2017). "Characteristics of Low-Priced Solar PV Systems in the United States." Applied Energy 187: 501-513.

O’Shaughnessy, E. 2018. The Evolving Market Structure of the U.S. Residential Solar PV Installation Industry, 2000-2016. NREL/TP-6A20-70545. Golden, CO: National Renewable Energy Laboratory.

O'Shaughnessy, E. 2018a. The Effects of Market Concentration on Residential Solar PV Prices: Competition, Installer Scale, and Soft Costs. NREL/TP-6A20-71296. Golden, CO: National Renewable Energy Laboratory.

Panzar, J., and R. Willig. 1981. "Economies of Scope.” Sustainability Analysis 71(2):268-272.

Pyper, J. 2018. "Everything You Need to Know about California's New Solar Roof Mandate." GreenTech Media. May 21, 2018.

Teece, D. 1980. "Economies of Scope and the Scope of the Enterprise." Journal of Economic Behavior and Organization (1980):223-247.

Tirole, J. 1988. The Theory of Industrial Organization. Cambridge, MA: The MIT Press. 


\section{Appendix: Regression Results}

This appendix provides the complete numerical results for the regression described in Section 4.2. A complete description of the control variables is provided in O'Shaughnessy (2018a).

Table A-1. Complete Regression Results

\begin{tabular}{|c|c|c|}
\hline & (1) & (2) \\
\hline Electrical & $\begin{array}{c}0.161 \\
(14.17)^{\mathrm{a}}\end{array}$ & $\begin{array}{r}0.161 \\
(14.07)^{\mathrm{a}}\end{array}$ \\
\hline Electrical x New Construction & & $\begin{array}{l}-0.072 \\
(0.93)\end{array}$ \\
\hline General Building & $\begin{array}{c}0.053 \\
(4.23)^{a}\end{array}$ & $\begin{array}{r}0.043 \\
(3.48)^{\mathrm{a}}\end{array}$ \\
\hline General Building x New Construction & & $\begin{array}{l}-0.361 \\
(1.96)^{b}\end{array}$ \\
\hline Solar Contractor & $\begin{array}{c}0.241 \\
(19.13)^{\mathrm{a}}\end{array}$ & $\begin{array}{r}0.225 \\
(17.94)^{\mathrm{a}}\end{array}$ \\
\hline Solar Contractor x New Construction & & $\begin{array}{c}0.129 \\
(0.78)\end{array}$ \\
\hline General Engineer & $\begin{array}{l}-0.261 \\
(9.15)^{\mathrm{a}}\end{array}$ & $\begin{array}{l}-0.248 \\
(8.70)^{a}\end{array}$ \\
\hline General Engineer $x$ New Construction & & $\begin{array}{c}0.259 \\
(1.05)\end{array}$ \\
\hline Roofing & $\begin{array}{l}-0.065 \\
(4.80)^{\mathrm{a}}\end{array}$ & $\begin{array}{l}-0.001 \\
(0.09)\end{array}$ \\
\hline Roofing $x$ New Construction & & $\begin{array}{r}-1.878 \\
(12.87)^{\mathrm{a}}\end{array}$ \\
\hline New Construction & $\begin{array}{c}-2.165 \\
(31.92)^{a}\end{array}$ & $\begin{array}{l}-0.936 \\
(5.78)^{\mathrm{a}}\end{array}$ \\
\hline $\mathrm{HHI}$ (market concentration) & $\begin{array}{c}-0.201 \\
(2.56)^{b}\end{array}$ & $\begin{array}{l}-0.253 \\
(3.25)^{\mathrm{a}}\end{array}$ \\
\hline Market size & $\begin{array}{c}0.044 \\
(10.32)^{a}\end{array}$ & $\begin{array}{r}0.046 \\
(10.87)^{\mathrm{a}}\end{array}$ \\
\hline Installer experience & $\begin{array}{c}-0.104 \\
(34.67)^{\mathrm{a}}\end{array}$ & $\begin{array}{c}-0.103 \\
(34.17)^{\mathrm{a}}\end{array}$ \\
\hline$\%$ third-party ownership in market & $\begin{array}{c}0.166 \\
(3.43)^{\mathrm{a}}\end{array}$ & $\begin{array}{r}0.168 \\
(3.50)^{\mathrm{a}}\end{array}$ \\
\hline Bill Savings (\$/W) & $\begin{array}{l}-0.093 \\
(3.48)^{a}\end{array}$ & $\begin{array}{l}-0.119 \\
(4.46)^{\mathrm{a}}\end{array}$ \\
\hline Up-front incentives $(\$ / W)$ & $\begin{array}{r}0.742 \\
(18.35)^{a}\end{array}$ & $\begin{array}{r}0.755 \\
(18.79)^{\mathrm{a}}\end{array}$ \\
\hline Ongoing incentives $(\$ / W)$ & $\begin{array}{l}-0.112 \\
(1.37)\end{array}$ & $\begin{array}{l}-0.062 \\
(0.77)\end{array}$ \\
\hline Sales tax $(\$ / W)$ & $\begin{array}{r}-21.700 \\
(7.01)^{a}\end{array}$ & $\begin{array}{r}-17.304 \\
(5.68)^{\mathrm{a}}\end{array}$ \\
\hline Household density & $\begin{array}{c}56.347 \\
(13.57)^{\mathrm{a}}\end{array}$ & $\begin{array}{r}54.898 \\
(13.30)^{\mathrm{a}}\end{array}$ \\
\hline $\begin{array}{l}\% \text { of households' education }>\text { bachelor's } \\
\text { degree }\end{array}$ & -0.008 & -0.008 \\
\hline & $(14.64)^{a}$ & $(15.51)^{\mathrm{a}}$ \\
\hline$\%$ of households $>\$ 100,000$ income & $\begin{array}{r}0.009 \\
(13.65)^{a}\end{array}$ & $\begin{array}{r}0.009 \\
(14.09)^{\mathrm{a}}\end{array}$ \\
\hline Labor cost index & $\begin{array}{c}0.000 \\
(2.44)^{b}\end{array}$ & $\begin{array}{r}0.000 \\
(1.63)\end{array}$ \\
\hline
\end{tabular}




\begin{tabular}{lcc}
\hline & $\mathbf{( 1 )}$ & $\mathbf{( 2 )}$ \\
\hline System size (kW) & -0.584 & -0.610 \\
& $(58.99)^{\mathrm{a}}$ & $(60.33)^{\mathrm{a}}$ \\
System size squared & 0.029 & 0.031 \\
& $(47.30)^{\mathrm{a}}$ & $(48.81)^{\mathrm{a}}$ \\
Module efficiency (\%) & 12.892 & 13.529 \\
& $(16.66)^{\mathrm{a}}$ & $(17.54)^{\mathrm{a}}$ \\
Module Cost Index & $\mathrm{X}$ & $\mathrm{X}$ \\
Inverter Cost Index & $\mathrm{X}$ & $\mathrm{X}$ \\
Utility Fixed Effects & $\mathrm{X}$ & $\mathrm{X}$ \\
Quarter Fixed Effects & $\mathrm{X}$ & 1.607 \\
Constant & 1.354 & $(5.26)^{\mathrm{a}}$ \\
& $(4.54)^{\mathrm{a}}$ & 0.51 \\
$R^{2}$ & 0.50 & 98,679 \\
$N$
\end{tabular}

a Statistically significant at $p<0.01,{ }^{b} p<0.05$ 